\title{
Erratum to: commentary on "carbon balance effects of US biofuel production and use," by DeCicco et al. (2016)
}

\author{
Robert D. De Kleine ${ }^{1}$ • Timothy J. Wallington ${ }^{1}$ • \\ James E. Anderson ${ }^{1}$ • Hyung Chul Kim ${ }^{1}$
}

Published online: 28 August 2017

(C) Springer Science+Business Media B.V. 2017

\section{Erratum to: Climatic Change \\ https://doi.org/10.1007/s10584-017-2032-y}

In the initial online publication, the name of author Hyung Chul Kim was misspelled as Hyung Chu Kim. The original article has been corrected.

The online version of the original article can be found at https://oi.org/10.1007/s10584-017-2032-y

Robert D. De Kleine

rdeklein@ford.com

1 Research \& Advanced Engineering, Ford Motor Company, Dearborn, MI, USA 